\title{
Representation by Percentage of the Tunicae of the Large Arteries in Chinchillas
}

\author{
Cristian MARTONOS ${ }^{1 *}$, Cristian DEZDROBITU ${ }^{1}$, Vasile RUS ${ }^{1}$, Viorel MICLĂUŞ${ }^{1}$, Irina IRIMESCU ${ }^{1}$, Aurel \\ DAMIAN $^{1}$ \\ ${ }^{1}$ University of Agricultural Sciences and Veterinarian Medicine, Cluj-Napoca, Romania \\ Corresponding author: martonosolimpiu@yahoo.com
}

Bulletin UASVM Veterinary Medicine 72(1) / 2015,

Print ISSN 1843-5270; Electronic ISSN 1843-5378

DOI:10.15835/buasvmcn-vm: 10491

\begin{abstract}
Chinchilla, a small sized rodent, is taxonomically placed in the Mamalia class, Theria subclass, Eutheria clade, Rodentia order, Hystricomorpha suborder, Chinchilidae family, Chinchilla species. In the wild, it occupies a territory covering the states of Chile, Peru and Argentina, as well as the south region of Bolivia. The biologic material for out study consisted of 5 Chinchilla specimens processed to obtain histological samples.

The staining protocol has very well underlined the trilamelar structure of the layers composing the arterial wall. The tunica intima comprises an endothelium, a basement membrane and a subendothelial layer. This tunic outlines the lumen of the arteries. The tunica media is formed by elastic fibers disposed on several circular layers and a certain number of smooth muscle cells in-between them. The external tunic or the tunica adventitia is made up of lax conjunctive tissue. The ratio between tunics of the arterial wall of the great arteries in Chinchillas changes according to the distance from the heart. While the aorta has a very poorly developed tunica adventitia, this layer represents $50 \%$ of the arterial wall in the subclavian and external iliac arteries.
\end{abstract}

Keywords: large arteries, representation by percentage, tunicae.

\section{INTRODUCTION}

Chinchilla, a small sized rodent, is taxonomically placed in the Mamalia class, Theria subclass, Eutheria clade, Rodentia order, Hystricomorpha suborder, Chinchilidae family, Chinchilla species. The arterial system of this species has few macroscopical descriptions and very fiew microscopical ones.

\section{AIMS AND OBJECTIVES}

The present study proposed a representation by percentage of the tunics composing the arterial wall in the large arteries of the chinchilla.

\section{MATERIALS AND METHODS}

The biological samples were harvested from 5 Chinchilla specimens, from a private husbandry, commercially slaughtered for fur. After the skinning, an anatomical dissection was performed, resulting in the identification of the arterial vessels and their harvesting. Immediately after the sampling, the arteries were fixed with a
$10 \%$ formalin solution, paraffin embedded, cut at $5 \mu$ and stained following the tricrom Goldner technique. The samples were harvested from the following arteries: the ascending aorta, the aortic arch, the left and right carotid arteries, the left subclavian artery, the descending thoracic aorta, the descending abdominal aorta, the left and right common iliac arteries and the left and right external arteries.

\section{RESULTS AND DISCUSSION}

The tunica intima is the most constant tunic, having a similar width in the studied arteries (aproximatively 5\%). The aorta, considered by Raica et al.(2004) as the reference artery for large arteries, is the largest vessel in the body. Mahammad et al. (2001) places the aorta in the elastic arteries category. In the chinchilla, the tunica adventitia represents aproximatively 10$15 \%$, while the tunica media represents $75-80 \%$ of the arterial wall. We have noticed that the rest or the aortic segments presented a similar structure 
as that of the ascending aorta. The subclavian arteries are also called brachial trunks (Damian 2007). By comparison to the cuts through the aorta, we have noticed that in those performed in the subclavian arteries, the tunica media occupies aproximatively $75 \%$ of the arterial wall's width, while the tunica adventitia represents aproximatively $20 \%$. The common carotid arteries (also called cephalic trunks) in the chinchilla originate in the brachiocephalic trunk. The left common carotid artery is the first branch emitted by the brachiocephalic trunk, at a short distance from the latter's detachment from the aortic arch. Keeping the same cranial path, the trunk also emits as terminals the right subclavian artery and the right common carotid artery (Özdemir V. et al., 2008). Comparing the common carotid arteries to the segments of the aorta in the chinchilla, it is noticeable that the ratio between the tunica media and the tunica adventitia suffers certain variations. Thus, in the common carotid arteries, the tunica media represents aproximatively 65$70 \%$, while the tunica adventitia represents aproximatively $25-30 \%$. The common iliac arteries in the Chinchilla lanigera are the terminals of the descending abdominal aorta, at the level of the L5-L6 vertebrae (A Çevik-Demirkana et al., 2010). Following the ratio between arterial tunics we notice that the external tunic of the common iliac arteries represents $40 \%$, while the tunica media represents aproximatively 55\% of the wall's width. The external iliac arteries in rabbits, horses and humans represent the direct continuation of the common iliac arteries (Barone, 1996; Stan et al., 2006). In the chinchilla, the external iliac arteries have a dorso-caudal path, being the true continuation of the common iliac arteries (Eken et al., 2005). Histologically, the external iliac arteries present structural differences comparable to the rest of the studied arteries. Thus, the tunica adventitia of these arteries represents aproximatively $50-55 \%$ of the arterial wall's width, while the tunica media represents only 40 $45 \%$ of it.

\section{CONCLUSION}

The representation by percentage of the arterial tunics presents major differences according to the topographical positioning of the arteries relative to the heart.

In the aorta segments, the tunica media is the most developed, representing $85 \%$ of the width of the wall, while the tunica adventitia represents aproximatively $10 \%$.

The width of the tunica media decreases progressively with the increase of the distance from the heart, while that of the tunica adventitia increases, so that the latter represents aproximatively $50 \%$ of the wall structure in the external iliac arteries.

Acknowledgements. This paper was published under the frame of European Social Fund, Human Resources Development Operational Programme 2007-2013, project no. POSDRU/159/ $1.5 / \mathrm{S} / 136893$

\section{REFERENCES}

1. Barone R (1996). Anatomie compare des mammiferes domestiques. Angiologie, Editions Vigot.

2. Çevik-Demirkana A, Özdemira V, Demirkan I (2010). The ovarian and uterine arteries in the chinchilla (Chinchilla lanigera). S Afr Vet Ass 81(1):54-57.

3. Damian A (2007). Anatomie comparată, Sistemul Cardiovascular. AcademicPres, Cluj-Napoca.

4. Eken E, Besoluk K, Teke BE (2005). An anatomical study on the conformation of the femoral artery in Chinchilla lanigera. Revue Méd Vét : 156, 10, 506-508.

5. Mohammad Abdul Awal, Mohammad Abdul Aziz Prodhan, Masamichi Kurohmaru, Mitsuharu Matsumotoand Hayao Hishinakagawa (2001). Microscopic studies on the arterial walls of main arteries supplying the mammary glands of guinea pig (Cavia porcellus) at different reproductive stages. VETERINARSKI ARHIV 71(1):19-30.

6. Özdemir V, Cevik-Demirkana A, Türkmenoðlu I (2008). Subgross and Macroscopic Investigation of Blood Vessels Originating from Aortic Arch in the Chinchilla (Chinchilla lanigera). Anat Histol Embryol 37:131-133.

7. Raica M, Mederle O, Căruntu Irina-Draga, Pintea Alina, Chindriş Anne-Marie (2004). Histologie teoretică şi practică, Brumar, Timișoara.

8. Stan F, Gudea A, Damian A, Papuc I (2006). Particularities of collaterals and terminals of external iliac arteries in horse. Buletinul Universitatii de Stiinte Agricole si Medicinã Veterinarã Cluj Napoca, seria Medicinã veterinarã, 63:166-169. 